Aspects of the Third Reich 


\section{Aspects of the Third Reich}

EDITED BY

H. W. KOCH

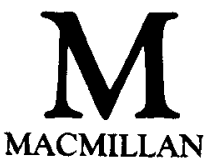


(C) H. W. Koch - Introductions to Parts I, II, III, IV and V, Selection and Editorial matter and Chapters 2 and 10; E. Nolte - Chapter 1; H. Mommsen - Chapter 3; L. Kettenacker Chapter 4; K.-J. Miller - Chapter 5; E. M.

Robertson - Chapter 6; H. R. Trevor Roper Chapter 7; D. Aigner - Chapter 8; W.

Michalka - Chapter 9; A. Milward - Chapter 11; B. H. Klein - Chapter 12; M. Broszat Chapter 13; B. Wegner - Chapter 14; W.

Carr - Chapter 15; Th. Nipperdey - Chapter 16. 1985

Softcover reprint of the hardcover 1st edition 1985

All rights reserved. No reproduction, copy or transmission of this publication may be made without written permission.

No paragraph of this publication may be reproduced, copied or transmitted save with written permission or in accordance with the provisions of the Copyright Act 1956 (as amended).

Any person who does any unauthorised act in relation to this publication may be liable to criminal prosecution and civil claims for damages.

First published 1985

Published by

Higher and Further Education Division

MACMILLAN PUBLISHERS LTD

Houndmills, Basingstoke, Hampshire

RG21 2XS

and London

Companies and representatives

throughout the world

Typeset by

Wessex Typesetters Ltd

Frome, Somerset

British Library Cataloguing in Publication Data

Aspects of the Third Reich.

1. Germany-History-1933-1945

I. Koch, H. W.

943.086 DD256.5

ISBN 978-0-333-35273-1 ISBN 978-1-349-17891-9 (eBook)

DOI $10.1007 / 978-1-349-17891-9$ 


\section{Contents}

Preface

vii

PART I

Introduction $\quad$ H. W. КосH 3

1 Between Myth and Revisionism? The Third Reich in the Perspective of the 1980 s

E. NOLTE

2 1933: The Legality of Hitler's Assumption of Power

H. W. KOCH

3 The Reichstag Fire and its Political Consequences H. MOMMSEN

4 Social and Psychological Aspects of the Führer's Rule

L. KETTENAGKER

5 The Structure and Nature of the National Conservative Opposition in Germany up to 1940 K.-J. MÜLLER

\section{PART II}

Introduction н. W. КОсH

6 Hitler's Planning for War and the Response of the Great Powers

E. M. ROBERTSON

7 Hitler's War Aims

H. R. TREVOR-ROPER

8 Hitler's Ultimate Aims - A Programme of World Dominion?

D. AIGNER 
9 From the Anti-Comintern Pact to the Euro-Asiatic Bloc: Ribbentrop's Alternative Concept to Hitler's Foreign Policy Programme W. MICHALKA

10 Hitler's Programme and the Genesis of Operation 'Barbarossa'

H. W. KOCH

\section{PART III}

Introduction H. W. KOCH

11 The Reichsmark Bloc and the International Economy

A. MILWARD

12 Germany's Economic Preparations for War

B. H. KLEIN

\section{PART IV}

Introduction H. W. косн

13 The Genesis of the 'Final Solution'

M. BROSZAT

14 The 'Aristocracy of National Socialism': The Role of the SS in National Socialist Germany

B. WEGNER

\section{PART V}

Introduction H. W. Косн 453

15 The Hitler Image in the Last Half-century 462 W. GARR

$16 \quad 1933$ and the Continuity of German History 489 TH. NIPPERDEY

Notes and References

Bibliography

Notes on Contributors 


\section{Preface}

This volume of essays on the Third Reich does not claim to cover it in anything like its entirety. As the title says only certain 'Aspects' have been selected which stand and will continue to stand for decades in the centre of historical debate.

The individual contributions are placed within the brackets, so to speak, of the contributions by Ernst Nolte at the beginning and Thomas Nipperdey at the end. Within these brackets five main areas are covered: first, the assumption and early consolidation of Hitler's power as well as the emerging conservative opposition. Secondly, aspects of National Socialist (NS) Germany's foreign policy. Thirdly, economic policy with regard to foreign trade with southeastern Europe, German rearmament and German economic policy during the Second World War. Fourthly, the subject of genocide will be re-examined and in connection with it Himmler's $S S$ empire. The fifth and final part deals with the problem of examining the Third Reich by concentrating on Hitler himself.

Instead of a general introduction the editor has preferred to write for each section a linking commentary in which not only is the reader's attention drawn to further literature on the subject, but also, wherever necessary, points raised in the individual essays are further amplified or additional debatable points discussed. Thus it is hoped an element of continuity will be given to the volume.

My thanks are obviously due to the contributors who have made their essays available for reprinting in this volume or who have written original contributions specifically for it. I am also indebted to Harvard University Press for permission to reprint excerpts from Burton H. Klein's Germany's Economic Preparations for War.

Last, but by no means least, I must express my gratitude to my colleague W. J. D. Trythall whose critical comments on the linking commentary were extremely valuable as were his suggestions for stylistic improvements. However, the 
viii

PREFACE

responsibility for their content is my own as is the selection of the individual essays from a virtually countless multitude on the subject. Within this volume there are unavoidable gaps, but if they did not exist this book would be a history of the Third Reich and not a consideration of certain of its aspects.

H. W. KOCH

Spring 1985 